\title{
All Teeth and Claws: Constructing Bears as Man- Eating Monsters in Television Documentaries
}

Michael Fuchs

\section{(2) OpenEdition \\ Journals}

Electronic version

URL: https://journals.openedition.org/ejas/12446

DOI: 10.4000/ejas.12446

ISSN: 1991-9336

Publisher

European Association for American Studies

\section{Electronic reference}

Michael Fuchs, "All Teeth and Claws: Constructing Bears as Man-Eating Monsters in Television Documentaries", European journal of American studies [Online], 13-1 | 2018, Online since 26 June 2018, connection on 08 July 2021. URL: http://journals.openedition.org/ejas/12446 ; DOI: https://doi.org/ 10.4000/ejas. 12446

This text was automatically generated on 8 July 2021.

Creative Commons License 


\title{
All Teeth and Claws: Constructing Bears as Man-Eating Monsters in Television Documentaries
}

\author{
Michael Fuchs
}

1 In 1997, an article published in Variety pointed out that while they were "[o]nce relegated to a few PBS specials about Siberian tigers and 'National Geographic' docus tracking endangered antelope, wildlife programs documenting every area of beasts and beastly behavior have exploded to the point where they are arguably the tube's hottest single genre" (Richmond 27). Before the launch of the Discovery Channel in 1985, nature programming "constituted a marginalized segment of TV production and distribution that could be found by viewers only on the fringes of an industry dominated by three commercial networks" (Chris loc. 1205). Discovery, however, turned nature documentaries into its brand identity, relying primarily on this genre to fill its schedule, especially in its first few years of operation. With the mainstreaming of wildlife documentaries, they increasingly embraced the spectacle of death, which has caused Peter Steinhart to diagnose a similarity between the moment in which a predator takes down their prey in a documentary film and the money shot characteristic of adult films. However, I would argue that contemporary wildlife documentaries centering on large predators tend to remediate horror film aesthetics, as viewers do not only constantly wait for the next kill, but also see the carnage in all its gory detail. In 1988, Discovery responded to the seemingly insatiable human appetite for audiovisual proof of large predators killing their prey by launching what has since become the television equivalent of the summer blockbuster: Shark Week.

2 Shark Week proved that "viewers flock in largest numbers to nature programs featuring top predators," as viewers are "fascinated by the 'violent natures' of the most spectacularly 'fanged and clawed' species" (Chris loc. 1534). The representation of sharks in the annual week-long special follows a particular pattern, as Matthew Lerberg has demonstrated. Jaws (1975), the original summer blockbuster, has had a lasting impact on the ways in which American popular culture depicts and understands sharks. 
The movie's title makes explicit what the shark stands for: the animal's voracious appetite. As Matt Hooper (Richard Dreyfuss), the film's resident marine biologist, emphasizes, the great white shark "is a perfect engine, an eating machine." Shark Week draws on the visual grammar established by Spielberg's movie by "reducing" sharks "to fin and jaws" (Lerberg loc. 971), thereby suggesting that the sharks depicted in Discovery's documentaries are as monstrous as the great white in the fiction film.

Tellingly, in 2012, Animal Planet launched its own week-long special modeled after Shark Week: Monster Week. Monster Week did, however, not simply materialize from a cultural vacuum; Animal Planet had repeatedly shown documentaries about "monstrous" animals, such as the two-hour special Giant Monsters with Jeff Corwin in 2009. In addition, the channel started to broadcast River Monsters in 2009. Discovery (Animal Planet's parent company) even acknowledged the influence of River Monsters on the creation of Monster Week, noting, "River Monsters has made a splash with Animal Planet viewers (the best-performing series in network history), so it's only natural that it would inspire something a bit bigger, a bit creepier," on its blog in May 2012 (Harris). The launch of Monster Week thus fed off a media environment which had accepted the equation of animals with monsters.

While this monster discourse remains implicit in Lerberg's discussion of Shark Week, it will take center stage in this essay. My article will examine two bear documentaries, the episode "Killers Bears" of the Animal Planet series Human Prey (2009) and the Maneaters episode "Bears" (2010). I will suggest that these two examples epitomize not only a specific type of bear documentaries, but a type of documentaries centering on large predators, more generally-documentaries which depict predator species as monsters which may endanger human lives. To be sure, Bill Nichols has explained that ideologies operate most forcefully "where there appears to be only natural and obvious meaning" (Ideology 5). "Film and television," Derek Bousé points out in his book Wildlife Films, "do not and cannot convey reality in its fullness, but have become quite adept at realism-that is, at giving convincing impressions of reality" (7; original italics). And there might be no representational context that communicates as "natural and obvious" a meaning as wildlife documentaries. After all, they suggest to viewers that they re-present (rather than represent) animals in their (more or less) "natural" habitat and strive to create the illusion that they provide viewers with "an unmediated, unedited experience of "Nature"' (Rothfels $\mathrm{x}$ ). However, in my contribution to this special issue, I will demonstrate that bears serve as monstrous projection screens for humans. Similar to such iconic monsters as Frankenstein's creature, the monstrous bears, however, do not only engender fears and anxieties, but also evoke sympathy in viewers. After all, these bears are not inherently monstrous; they only become monsters when they encounter human beings.

\section{Monstrous Bears}

5 Tellingly, in their journal entries of May 5, 1805, William Clark and Meriwether Lewis portray a grizzly bear as a "verry large and a turrible looking animal," which was "extreemly hard to kill" (it took the party ten shots to get the bear down). After having examined the dead mammal in more detail, Lewis concluded that the animal was a "monster." Lewis and Clark's descriptions may be considered the beginning of depicting the grizzly bear "as a ravening, snarling, bloodthirsty beast" (Schullery 101); 
however, in the context of this essay, the performative gesture of labeling the grizzly a monster is more important, as it transforms the bear into a monstrous creature. Indeed, linguists Mark Johnson and George Lakoff have suggested that symbols shape our everyday experiences: "The concepts that govern our thought are not just matters of the intellect. ... Our concepts structure what we perceive, how we get around the world, and how we relate to other people [and nonhuman animals]. Our conceptual system ... plays a central role in defining our everyday realities" (3). Thus, referring to a grizzly as a "monster" influences our understanding of these animals, as we linguistically mold the raw material provided by the actual animal body into a symbol, thereby creating a monster. Indeed, "[a]ll monsters," Asa Mittman has remarked, "are our constructions, even those that can clearly be traced to 'real,' scientifically known beings[.] ... [W]e construct or reconstruct them, we categorize, name, and define them, and thereby grant them anthropocentric meaning that make them "ours"' (1).

6 The word "monster" can be traced to the Latin word monstrum, which denotes an abnormal shape, on the one hand, and a sign, on the other. Monstrum, on its end, derives from the root monere, which translates as "to warn." The word "monster" thus suggests both a warning sign and something out of the ordinary. According to the Oxford English Dictionary, when "monster" entered the English language, the word meant "a mythical creature which is part animal and part human, or combines two or more animal forms, and is frequently of great size and ferocious appetite" ("Monster"). Importantly, before human beings used animals and human-animal hybrids in these symbolic ways, large predators had threatened the lives of humans for millions of years (Trout loc. 272). The employment of animals as metaphors was thus anchored in the close contact between early humans and nonhuman species (Berger 14-19).

The increasing differentiation between the domains humans and animals inhabit most likely resulted from the emergence of agriculture and the attendant domestication of animals. In this period of human history, "a new concept of animals and humans emerged, with humans transcending and controlling animals and nature" (DeMello 34). The rigid demarcation between the artificial, ordered, and cultured sphere of the human and the natural, chaotic domain of nature "creates two entirely distinct ontological zones: that of human beings on the one hand; that of nonhumans on the other" (Latour 10-11).

8 The seemingly unbridgeable chasm which separates human from nonhuman animals (along with the natural world at large) opens up a connection to monsters. After all, monsters are, as Jeffrey Jerome Cohen puts it in his seven theses on monstrosity, "difference made flesh" (7). They are "our others par excellence. Without them we know not what we are" (Kearney 117; original italics). Indeed, the self needs others in order to define itself. In The Open (2002), Giorgio Agamben likewise explains that the "anthropological machine" produces "the human" by constructing differences to nonhuman animals. Thus, the human depends on the animal; "man originates from animal" (loc. 347). On the other hand, as Tim Ingold has concluded, "Every attribute that is claimed we uniquely have, the animal is consequently supposed to lack; thus, the generic concept of 'animal' is negatively constituted by the sum of these deficiencies" (3). Accordingly, the conceptual categories of "the human" and "the animal" mutually constitute one another, for human is that which is not animal, while animal is that which is not human (even though, taxonomically speaking, humans are part of the animal kingdom; i.e., human is animal, while animal need not be human). 
Cultural practice imagines this conceptual separation in spatial terms, as cultures are founded upon topological binaries, which are always ripe with meaning (Lotman 131). Space, as Henri Lefebvre has shown, is simultaneously produced by social practice and constitutes social life; space-along with the cultural ballast it carries-shapes human actions. Likewise, Michel Foucault has highlighted the ways in which space is interrelated with regimes of power: Space serves practices of inclusion and exclusion, thereby managing social difference.

Both "Killer Bears" and "Bears" tell stories in which humans and/or animals are repeatedly "out of place" (Brownlow 147), as the clear borderlines separating the world of humans from the world of bears fade away, since the species increasingly inhabit overlapping spaces. In "Bears," the opening voice-over narration tellingly stresses, "In the past, bears were rarely seen. But now, as human populations are expanding, our worlds are colliding-and conflicts are rising." While large predator attacks on humans have been increasing dramatically since the 1990s (see Penteriani et al.), "bear attacks are rare events" (Herrero viii). Indeed, an average American is ten times more likely to die from a dog attack than from a bear attack. And more than $50 \%$ of animal-related human fatalities in the United States are caused by farm animals and the group of hornets, wasps, and bees (Forrester, Holstege, and Forrester). Of course, these numbers are slanted, since, on any given day, there are thousands of times more encounters between humans and dogs, humans and farm animals, and humans and these insects, respectively, than human-bear encounters. However, media representations of bear attacks (and attacks by any large predator, more generally) are just as unbalanced.

Notably, "Bears" acknowledges that $98 \%$ of grizzly bear attacks are, in fact, on hunters -as they move silently through the underbrush and bears (and other predators) have learned to associate the sound of a rifle with easy prey-and black bear attacks "are rare." Still, the documentaries' structure suggests that bear attacks occur at an alarming rate. Describing a standard strategy in wildlife documentaries, Christopher Parsons has remarked that filmmakers cram "in as many incidents and confrontations with other species as time will allow." While "these confrontations can happen in nature, ... they occur only very occasionally, even when they are direct predator/prey relationships" (16). The same approach is at work in the two Animal Planet documentaries. In "Killer Bears," three violent human-bear encounters are packed into 48 minutes of runtime; "Bears" is even more intense, featuring five encounters in 39 minutes.

\section{Creating Monsters}

This conscious manipulation of time by controlling the rhythm of the attacks demonstrates that wildlife documentaries do not simply capture reality. "Of course, all cameras lie" (97), David Attenborough, the famous voice of numerous BBC nature documentaries, remarked in a lecture in 1961. Documentaries create the illusion of authenticity, but they are bound by institutional and cultural contexts. These frameworks require a specific "way of seeing and speaking, which functions as a set of ... conventions ... for the filmmaker and the audience alike" (Nichols, Introduction 17). As a result, documentaries-similar to fiction films-are "suspended somewhere between representation and simulation of nature-between truth and fiction, science and storytelling" (Bousé 16). 

and are composed of five core elements: (a) snippets of interviews with survivors and eyewitnesses of bear attacks, (b) audiovisual reconstructions of the attacks, (c) photographs of the wounds the bears inflicted, (d) voice-over narration, and (e) additional interviews with animal behaviorists, park rangers, and other people knowledgeable about bears. The expert interviews are primarily explanatory, trying to explain the bears' actions.

14

The main interview segments allow average people who experienced bear attacks firsthand (or witnessed attacks from close vicinity) to tell their stories to the audience. Since the interviewer is invisible, these interviews create the illusion as if the interviewees were speaking directly to the audience. These are testimonies by people who have made experiences the audience cannot quite understand; testimonies which produce authenticity, as the bear attacks become anchored in material reality. The interviewees' framing-placed in a nondescript room, primarily filmed in medium close-ups-adds to the realism of their past encounters, as their temporal and spatial distance from the action allows them to provide relatively objective reflections and conclusions-which are, of course, anchored in their subjective experiences. In terms of content, the interviews have one aspect in common-all highlight the bears' incredible power, speed, and ferocity. In "Killer Bears," Kelly McConnell, for example, reports that he "just felt helpless, while in "Bears," Johan Otter remarks, "I never knew that a bear was this strong. It's one big clump of muscle." 1

The voice-over narration underscores the brutality of the attacks. For example, when describing an incident at Liard River Hot Springs Provincial Park in British Columbia, the "Killer Bears" narrator uses language with a clear goal. Patti McConnell walks "into a death trap" and is "frozen with fear" when she spots the bear. Moments later, "[ $t]$ he 400-pound beast viciously attacks Patti. ... The bloodthirsty beast tears into Patti." ${ }^{2}$ When a man tries to save her, "[t]he bear's reaction is explosive," as the animal kills the intruder in a heartbeat and begins to feed on the human body. Alerted by the noise, more people arrive at the scene and "desperately try to keep the furious bear away from Kelly [McConnell] and his mom [i.e., Patti]." However, they soon come to understand that the "only way to end the carnage is by killing the bear. ... But this vicious predator is not done with his bloody rampage." As the bear gets closer to another group of people, "running bodies trigger the bear's killer instinct. The massacre won't end until someone kills the crazed beast." The numerous plosives and sibilants used to describe the bear and his actions support the traits ascribed to him and the words referring to him: The bear is a bloodthirsty, crazed beast that viciously massacres human beings (which, on top, are only "bodies") on a bloody rampage and leaves behind carnage. Clearly, this bear is a monster hungry for human meat.

16 The reconstructions of the bloody encounters follow a similar goal. During the attacks, rapid cuts move back and forth between the victim's point of view, the bear's point of view, and a third, more objective, perspective. The camera is constantly shaking, trying to visually capture the chaos and the brutality of the attack in question. The bear repeatedly opens his mouth and recurrently growls, while human screams are practically omnipresent. In-between, viewers can hear bones cracking and-sometimes -the bear's lips smacking, indicating that the predator has started to eat his prey.

Stylistically, the bear attacks call to mind the way horror films depict murder scenes. In particular, the bear's point of view (Fig. 1) provides a clear reference to the iconic 
opening scene of Jaws (which arguably drew on the opening of the 1953 movie The Beast from 20,000 Fathoms). Vera Dika has explained that the subjective perspective characteristic of slasher movies allows viewers to experience the events from the point of view of an "unknown character, figuratively occupying his position within the film's space" (36). Crucially, while the first-person perspective at first might suggest identification with the bear whose body viewers are invited to inhabit, the exact opposite is the case. The bear "lacks all personality and its motives are nonexistent [sic]. It becomes known only through its body and aggressive actions: it is constructed as an acting body" (Aaltola). The documentaries thus underline the difference between humans and animals: whereas humans "are intentional, rational and moral heroes" (indeed, seven of the eight stories about bear encounters feature heroic people trying to fight off the bears), the bear is little more than "an instinctually violent body that is unseen, unknown-and frightening" (Aaltola).

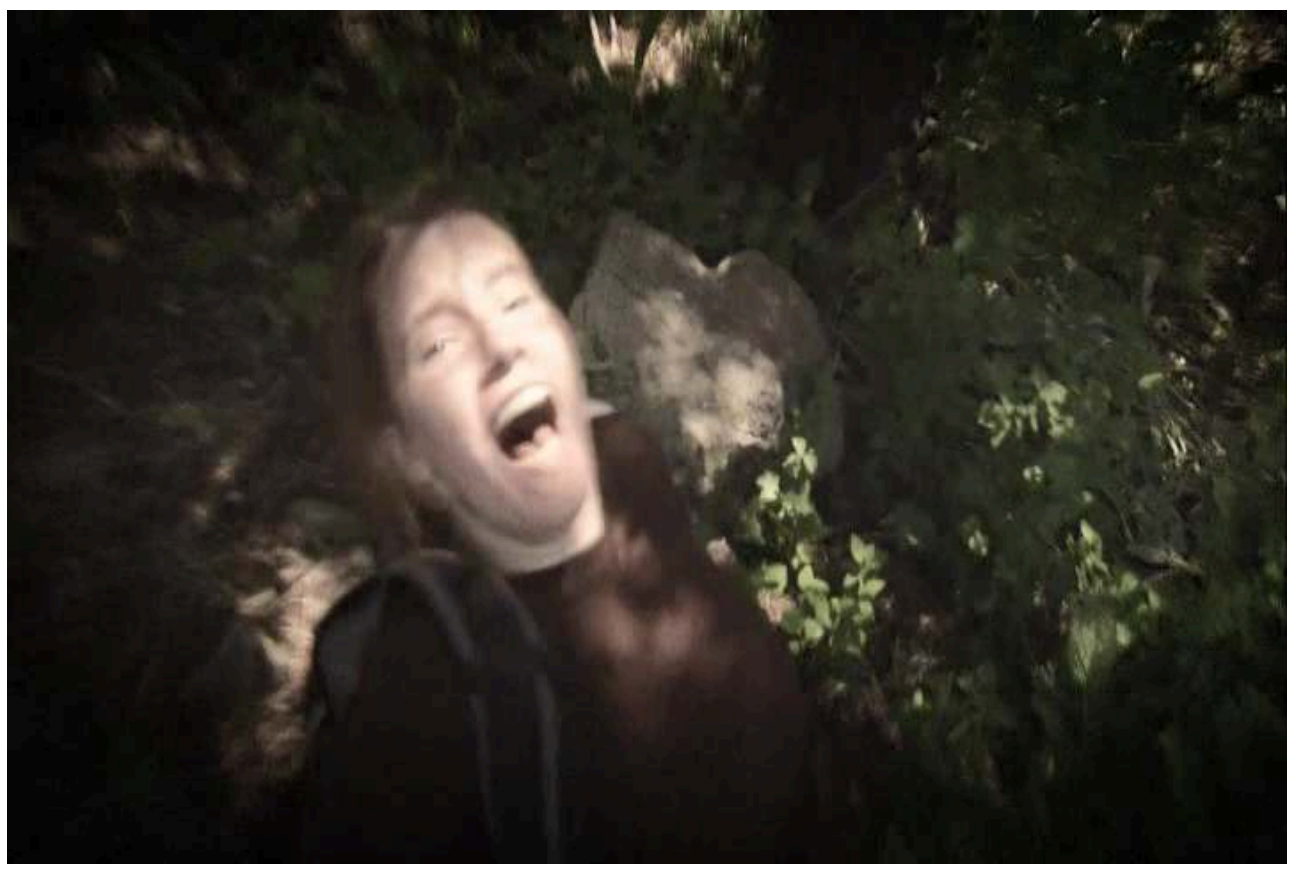

Fig. 1: The camera assumes the bear's point of view as he closes in for the attack. Screenshot from "Bears" @ Discovery Communications, 2010.

In addition, whereas John Berger has claimed that "animals are always the observed" (27), the documentaries imply that bears, in fact, observe humans, always waiting for the opportunity to pounce on them. In this way, "Bears" and "Killer Bears" suggest that in a real-life situation, the human does not have the active, controlling gaze. However, the large-scale implications of this acknowledgment of the realities of life on this planet are nullified by the media apparatus, which not simply frames all of these moving images, but rather becomes a symbol "of the technical prowess required to 'produce' nature" (Pick 24). The human viewers, presumably sitting in front of their TV sets in the safety of their homes, look at the (television representations of) bears looking at prey, thereby creating the illusion of mastering the situation.

Tellingly, whenever the stylization of the reconstructions is on the verge of becoming too intrusive, the recreations of these past moments are replaced by photographs of the eventual outcomes of the attacks (see Figs. 2 and 3). In this way, the television documentaries draw on photography's aura of authenticity in an intermedial gesture. In his reflections on photography, Roland Barthes explains that (analog) photography 
requires a "real thing which has been placed before the lens," since without the material object, "there would be no photograph" (76). However, Barthes does not promote an overly simplistic understanding of photographs as "'copies' of reality" (88); rather, photographs "emanat[e a] past reality," as they are assumed to capture reality and are thus endowed with "an evidential force" (89), which creates the illusion of an indexical reference to a past reality. Tellingly, the photographs display horrifying wounds, which seek to engage viewers affectively by drawing their attention to their own organic existences.
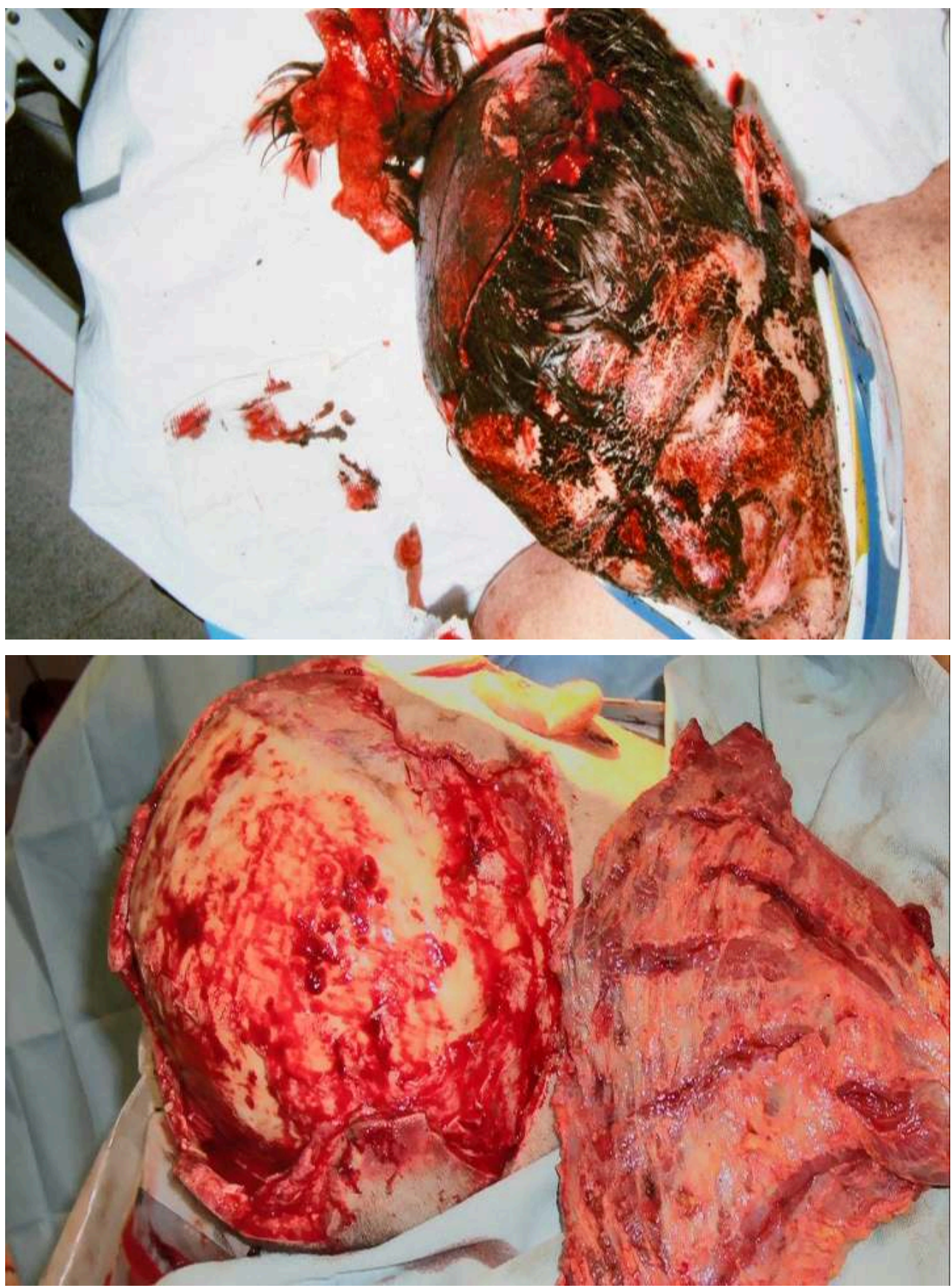

Figs. 2 \& 3: The wounds a female grizzly inflicted on Johan Otter in 2005. Screenshots from "Bears" (c) Discovery Communications, 2010. 


\section{3. (Nearly) Eating Humans}

20 On another level, this return to the material reality of the human body is intricately interwoven with a threat the bears embody: "It's everyone's worst nightmare: Being eaten alive by a wild animal," the voice-over narrator in "Killer Bears" announces early on. No scholar seems as competent to discuss the encounter with a large predator as early feminist ecocritic Val Plumwood. After all, a large saltwater crocodile attacked her while she was kayaking in Australia's Kakadu National Park in 1985.

21 In her reflections on the nearly fatal encounter, Plumwood notes that she "had given insufficient attention ... to [her] own vulnerability as an edible, animal being" (10). When the crocodile struck her, one of the first thoughts crossing her mind was that "[t]he creature was breaking the rules, was totally mistaken, utterly wrong to think [she] could be reduced to food" (12). Even though Plumwood had commented on the implications of anthropocentrism for more than a decade when the crocodile attacked her, her thoughts were deeply entrenched in the very discourses she had critiqued. While, in her writings on the attack (penned more than a decade after the fact), she demonstrates an awareness of these issues and nearly ridicules herself for her past naïveté, she repeatedly appears to establish overly simplistic binaries separating "us" (humans) from "them" (animals) and taps into discourses that transform the actual crocodile into something other than a crocodile.

Indeed, she describes the saltwater crocodile as "a predator of humans from the distant past" (10). While Plumwood (most probably) employed these exact words to highlight Westerners' tendency to suppress aspects of human existence which contradict the master narrative of human progress, her phrasing takes on Freudian overtones. After all, Freud argued that "the uncanny ... is something ... which has undergone repression and then returned from it," which includes that which "recalls repressed desires and surmounted modes of thinking belonging to the prehistory of ... the race" (245). Like any monster, the bears in the two Animal Planet documentaries arguably function as embodiments of the return of the repressed, as their wildness comes to symbolize everything humankind has repressed (and/or suppressed) because of the progress of civilization.

However, this interpretation removes the corporeal experience from the equation-but this bodily dimension of the encounter with a large predator is important, as it anchors accounts of animal predation on humans in lived reality. "The monstrous body" may be "pure culture" (Cohen 4), but the grizzly bears and black bears in the documentaries also exist (or, rather, existed) in material reality. Indeed, while scholars in the environmental humanities might be quick to point out Plumwood's binary thinking, which arguably oversimplifies the entangled nature of our worldly existences, these binaries ground the discussion of the place of the human in the biosphere in a realworld experience. When you encounter a grizzly bear or a black bear in the wild, the animal may consider questions such as whether you are a potential threat (accompanied by the basic question "flight or fight?") or maybe even a potential food source. If the bear were to decide to move toward you, your fragile human body would not stand much of a chance, and the corporeal encounter would also come down to a binary-live or die. visuals, in combination with the screams and sounds of bones cracking and bears 
feeding on humans, in fact, undermine the mastery of the image by assaulting viewers, utilizing what Steven Shaviro has called "the visceral immediacy of cinematic experience" (36). Drawing on horror aesthetics, these documentaries affect viewers; they make their bodies flinch and respond in other corporeal ways in an attempt to reproduce the monstrous force of these animals through the televisual encounter with them.

\section{Sympathy for the Monster}

While the documentaries thus depict black bears and grizzly bears as creatures human beings should not simply respect, but rather fear, "Bears" and "Killer Bears" do, in fact, acknowledge that humans primarily shape human-bear relations and that the bears are generally not to blame for these violent encounters. In "Bears," Drake Stephens, introduced as a "Human/Bear Conflict Advisor," explains that "our population is growing, the black bear's population's growing, and we're competing for the same space." Similarly, Kevin Frey of Montana Fish \& Wildlife Parks remarks that grizzlies "need a lot of space; and they probably need a lot of space away from us" ("Bears"). However, instead of giving them the space they need, animals are "driven from their homes by logging, mining, agriculture, and urbanization" (Wolch and Emel xi) due to the increasing human overpopulation of the planet.

Scientists have added two more reasons for the increase in carnivore attacks on humans: On the one hand, "the contemporary conservation paradigm" may have created "an increasing number of bold individuals" who are no longer afraid of humans (Penteriani et al.). On the other hand, "risk-enhancing human behavior" increases exponentially, as people from developed countries no longer know how to interact with wild animals (Penteriani et al.). This dimension is intricately interrelated with the media. John Berger has argued that "the widespread ... diffusion of animal imagery ... began as animals started to be withdrawn from daily life" (35). "The reproduction of animals in images" only amplified this process and made "animals ever more exotic and remote" (Berger 36). As animals vanish "from the immediate world, they ... reappear... in the mediated world of technological reproduction" (Lippit loc. 398). As the representations and simulations of animals thus replace actual animals, our relationship to, and with, them changes, as well, for, ensnared in "a shroud of cinematic [and televisual] conventions" (Bousé 8), the connection between the representation and its real-world referent is lost. Our understanding of (and for) an actual encounter with a wild animal is lost. Our link to the "natural" world is lost.

However, Johan Otter offers a modicum of hope in his recreation of his bear encounter. When looking at the female grizzly during the attack, he came to understand that "all the animal wanted to do was ... eliminate the threat, the threat for its cubs." $\mathrm{He}$ continues, "That made me kind of feel connected, because I was doing the exact same thing: I was protecting my cub" ("Bears"). The life-threatening situation thus allowed Otter "to arrive at some comprehension of what it means to be-with other individuals of different yet related species" (Acampora 27; original italics). The question is, of course, whether only a nearly fatal encounter with a predator can allow us to grasp the entangled nature of life on this planet. 


\section{BIBLIOGRAPHY}

Aaltola, Elisa. "Animal Monsters and the Fear of the Wild." $M / C$ Journal: The Journal of Media and Culture 5.1 (2002). Web. 15 Jan. 2018.

Acampora, Ralph R. Corporal Compassion: Animal Ethics and Philosophy of the Body. Pittsburgh: U of Pittsburgh P, 2006. Print.

Agamben, Giorgio. The Open: Man and Animal. Trans. Kevin Attell. Stanford: Stanford UP, 2004. Kindle.

Attenborough, David. "Honesty and Dishonesty in Documentary Filmmaking." The Photographic Journal 101 (1961): 97-102. Print.

Barthes, Roland. Camera Lucida: Reflections on Photography. Trans. Richard Howard. New York: Hill \& Wang, 1981. Print.

Berger, John. “Why Look at Animals?” Why Look at Animals? London: Penguin, 2009. 12-31. Print.

Bousé, Derek. Wildlife Films. Philadelphia: U of Pennsylvania P, 2000. Print.

Brownlow, Alec. "A Wolf in the Garden: Ideology and Change in the Adirondack Landscape." Animal Spaces, Beastly Places: New Geographies of Human-Animal Relations. Ed. Chris Philo and Chris Wilbert. London: Routledge, 2000. 143-160. Print.

Chris, Cynthia. Watching Wildlife. Minneapolis: U of Minnesota P, 2006. Kindle.

Cohen, Jeffrey Jerome. “Monster Culture (Seven Theses).” Monster Theory: Reading Culture. Ed. Jeffrey Jerome Cohen. Minneapolis: U of Minnesota P, 1996. 3-25. Print.

DeMello, Margo. Animals and Society: An Introduction to Human-Animal Studies. New York: Columbia UP, 2012. Print.

Dika, Vera. Games of Terror: Halloween, Friday the $13^{\text {th }}$, and the Films of the Stalker Cycle. Rutherford, NJ: Associated UP, 1990. Print.

Forrester, Jared A., Christopher P. Holstege, and Joseph D. Forrester. "Fatalities from Venomous and Nonvenomous Animals in the United States (1999-2007)." Wilderness \& Environmental Medicine 23.2 (2012): 146-152. Web. 15 Jan. 2018.

Foucault, Michel. The Birth of the Clinic: An Archaeology of Medical Perception. Trans. Alan M. Sheridan. New York: Routledge, 1976.

---. Discipline \& Punish: The Birth of the Prison. Trans. Alan Sheridan. New York: Vintage, 1995. Freud, Sigmund. "The 'Uncanny.”" 1919. Trans. James Strachey, Alix Strachey, and Alan Tyson. The Standard Edition of the Complete Psychological Works of Sigmund Freud, Vol. 17: An Infantile Neurosis and Other Works. London: Vintage, 2001. 217-256. Print.

Harris, Amber. “Tonight Marks the Start of 'Monster Week' on Animal Planet.” Discovery Blog. 21 May 2012. Web. 15 Jan. 2018.

Herrero, Stephen. Bear Attacks: Their Causes and Avoidance. Rev. ed. Guilford, CT: Lyons Press, 2002. Print.

“Human Prey: Killer Bears” [“Killer Bears”]. Maneaters: Bears. Discovery, 2012. DVD.

Ingold, Tim. "Introduction.” What is an Animal? Ed. Tim Ingold. London: Routledge, 1988. 1-14. Print. 
Jaws. Dir. Steven Spielberg. Universal Pictures, 2012. Blu-ray.

Kearney, Richard. Strangers, Gods and Monsters: Interpreting Otherness. London: Routledge, 2003. Print.

Lakoff, George, and Mark Johnson. Metaphors We Live By. Chicago: U of Chicago P, 1980. Print.

Latour, Bruno. We Have Never Been Modern. Trans. Catherine Porter. Cambridge, MA: Harvard UP, 1993. Print.

Lefebvre, Henri. The Production of Space. Trans. Donald Nicholson-Smith. Oxford: Basil Blackwell, 1991. Print.

Lerberg, Matthew. "Jabbering Jaws: Reimagining Representations of Sharks Post-Jaws." Screening the Non-Human: Representations of Animal Others in the Media. Ed. Amber E. George and J. L. Schatz. Lanham, MD: Lexington Books, 2016. Kindle.

Lippit, Akira Mizuta. Electric Animal: Toward a Rhetoric of Wildlife. Minneapolis: U of Minnesota P, 2000. Kindle.

Lotman, Yuri M. Universe of the Mind: A Semiotic Theory of Culture. Trans. Ann Shukman. London: I. B. Tauris, 1990. Print.

"Maneaters: Bears" [“Bears"]. Maneaters: Bears. Discovery, 2012. DVD.

“May 5, 1805.” Journals of the Lewis \& Clark Expedition. Web. 15 Jan. 2018.

Mittman, Asa Simon. "Introduction: The Impact of Monsters and Monster Studies." The Ashgate Research Companion to Monsters and the Monstrous. Ed. Asa Simon Mittman and Peter J. Dendle. New York: Routledge, 2016.1-14. Kindle.

“Monster." Oxford English Dictionary. Web. 15 Jan. 2018.

Nichols, Bill. Ideology and the Image: Social Representation in the Cinema and Other Media. Bloomington: Indiana UP, 1981. Print.

---. Introduction to Documentary. $2^{\text {nd }}$ ed. Bloomington: Indiana UP, 2010. Print.

Parsons, Christopher. Making Wildlife Movies. Newton Abbot: David \& Charles, 1971. Print.

Penteriani, Vincenzo, et al. "Human Behaviour Can Trigger Large Carnivore Attacks in Developed Countries." Scientific Reports 6 (2016): 20552. Print.

Pick, Anat. "Three Worlds: Dwelling and Worldhood on Screen." Screening Nature: Cinema beyond the Human. Ed. Guinevere Narraway and Anat Pick. London: Berghahn, 2013. 21-36. Print.

Plumwood, Val. "Meeting the Predator." The Eye of the Crocodile. Ed. Lorraine Shannon. Canberra: Australian National UP, 2012. 9-21. Ebook.

Richmond, Ray. “Critter TV Not Just for Cable Anymore.” Variety (30 June-13 July 1997): 27. Print.

Rothfels, Nigel. "Introduction." Representing Animals. Ed. Nigel Rothfels. Bloomington: Indiana UP, 2002. vii-xv. Print.

Schullery, Paul. Lewis and Clark among the Grizzlies: Legend and Legacy in the American West. Lanham, MD: Rowman and Littlefield, 2002. Print.

Shaviro, Steven. The Cinematic Body. Minneapolis: U of Minnesota P, 1993. Print.

Steinhart, Peter. "Ecoporn.” Audubon 85.3 (1983): 22-25. Print.

Trout, Paul A. Deadly Powers: Animal Predators and the Mythic Imagination. Amherst, NY: Prometheus, 2011. Kindle. 
Wolch, Jennifer, and Jody Emel. "Preface." Animal Geographies: Place, Politics, and Identity in the Nature-Culture Borderlands. London: Verso, 1998. xi-xx. Print.

\section{NOTES}

1. Johan Otter has since written a book about how his-and his daughter's-life changed after the encounter with the bear, A Grizzly: A Father and Daughter Survival Story (2016).

2. All emphases in this paragraph added by the author.

\section{ABSTRACTS}

Since the mid-1980s televised wildlife documentaries have become increasingly spectacular. In particular, documentaries revolving around large predators have not just proliferated, but supported entire networks, as evidenced by Discovery's Shark Week, which has enjoyed a phenomenal success since its introduction in 1988. Shark Week, as Matthew Lerberg (2016) has shown, epitomizes the representational reductionism which operates across media-sharks are nothing but fin and jaws. Drawing on audiovisual conventions established by Jaws, sharks tend to be depicted as monsters-even in programs with didactic and/or conservationist goals. In this article, I explore representations of another large predator family, bears, in two Animal Planet documentaries. As I show, the monstrous bears embody human anxieties, but they also invite human sympathy, as human beings have turned them into monsters.

\section{INDEX}

Keywords: Animal Planet, grizzly bears, black bears, wildlife documentaries, monstrosity

\section{AUTHOR}

\section{MICHAEL FUCHS}

Michael Fuchs is a fixed-term assistant professor in the Department of American Studies at the University of Graz. He has co-edited five books and (co-)authored more than forty published and forthcoming articles and book chapters on horror films, American television, video games, adult films, fan cultures, comics, and American sports. For additional information on his past and ongoing research, check out his website at www.fuchsmichael.net. 